\title{
Uma identidade americana pluri-racial e pluri-religiosa: a África negra e Moby Dick, de Melville
}

\author{
VIOLA SACHS
}

$\mathrm{J}$ OSÉ BONIFÁCIO descrevia o Brasil como uma nação mestiça; o seu contraparte norte-americano, Thomas Jefferson, afirmava que brancos e pretos nunca poderiam coabitar nem se misturar. Escrevia que era difícil prever qual das duas raças predominaria e lamentava-se que, por razões econômicas, não era possível mandar africanos de volta para a terra deles. Isso não o impediu de ter uma relação amorosa com uma de suas escravas; mas seus descendentes não foram convidados para a celebração dos 200 anos da sua famosa fazenda.

A identidade norte-americana se constituiu muito conscientemente, já no tempo da colônia, em torno da brancura, da masculinidade (oposta à feminilidade) e da religião cristã em oposição ao catolicismo e às religiões pagãs.

Veremos a que ponto Melville desmantela toda essa construção que rejeita incondicionalmente o Outro. Não há dúvida de que isso se explica em parte por ele ter sido marinheiro a bordo de uma baleeira, o que o levou a encontrar marinheiros de recantos longínquos e certamente da África Ocidental, principalmente bambaras e malis. Sua vivência durante alguns meses no meio de selvagens das ilhas Marquesas (em seus romances Typee e Omoo descreve-os como canibais) sensibilizou-o a outras culturas, outros modos de ser e outros modos de comunicação. No entanto, seu contemporâneo Thoreau, cuja vida se limitou em grande parte ao espaço da Nova Inglaterra, escreve na Conclusão à sua obra-prima Walden (1854) que "é ridícula a exigência da Inglaterra e dos Estados Unidos que se fale [a notar a insistência sobre a oralidade] de maneira a que possam entendê-lo". Várias referências à África precedem essa queixa, sugerindo por esse meio que, para perceber todas as dimensões do livro, o leitor precisaria possuir um conhecimento das culturas africanas.

A presença cultural africana - que já se acha, oculta, nos grandes livros de escritores brancos do período que precede a Guerrra da Secessão (1861-1865) foi e continua sendo até certo ponto ignorada pelos universitários norte-americanos brancos do sexo masculino. Isso se explica pelo fato de que, até os anos 
1970, eles permaneciam cegos ao fato de os africanos e afro-americanos possuírem culturas ricas (1) e sofisticadas, embora muito diferentes do que chamamos de cultura ocidental, cultura escrita, intelectual. Na cultura afro-americana, a ênfase cai sobre a capacidade de ver, olhar, ouvir, sentir, cheirar, tocar. Importam os sons, as danças, as cores, os elementos, o corpo tão negado na cultura branca norte-americana. As formas verbais "olhe", "veja”, "escute”, "ouça”, "toque”, "cheire", "penetre" incitam o leitor a penetrar o texto inglês, a descobrir o que ele esconde, a se aventurar no labirinto de imagens, sinais e sons para descobrir outras maneiras de sentir o livro, como algo de animado, livro que se transforma numa baleia preta que parece branca e que se desloca simultaneamente no espaço, no mar, no tempo.

O esquema sumário que segue permite compreender melhor como se estruturou a identidade nacional no imaginário do homem branco (2) na época que precede a Guerra da Secessão, época em que Melville escreve Moby Dick (1851). Polaridades irredutíveis marcam (e continuam a marcar até hoje) esse imaginário; é importante compreender que os elementos ditos positivos formam um todo e, como tal, não se opõem aos negativos. Assim, por exemplo, o feminino pertence ao mundo noturno, diabólico, animalesco, assimilado a seres de cor etc.

Deus

Cristianismo (protestante)

Civilização / ordem

Luz / dia / brancura

Homem branco / o masculino

(the white man)

Mente / razão

A verdade / sentido único

Lado direito (right) / certo

Dinheiro / dólar / possuir

Língua inglesa / escrita alfabética
Diabo / divindades pagãs

Outras religiões e crenças / paganismo Selvático (wilderness) / labirinto

Escuridão / noite / preto (blackness) Mulher / o feminino, o negro, o índio (designados em inglês pela cor: the black man, the red man, o que explica a conotação negativa dessas cores)

Corpo / instinto / intuição / coração Mentira / erro / polissemia Lado esquerdo Amor / amizade / partilhar Outras línguas / oralidade / pictogramas / hieróglifos

As pesquisas feitas no Laboratoire de Recherche sur l'Imaginaire Américain trouxeram à luz a forma iniciática dos textos que giram em torno do problema da identidade dos Estados Unidos, do Novo Mundo visto como uma recriação do mundo. Os escritores rejeitam, desmantelam a identidade nacional tal como ela se apresenta. A pressão social não lhes deixa espaço para se exprimirem francamente - ainda que os escritos, mesmo a nível de primeira leitura, sejam críticos da realidade norte-americana. 
O texto inglês, com sua narração, seus personagens, suas letras alfabéticas imobilizadas, presas na página branca, se refere à realidade norte-americana. Numerosas indicações mais ou menos explícitas levam o leitor atencioso a se aventurar numa escrita labiríntica formada de teias sem fim, tecidas de redes de associações, analogias, correspondências entre imagens e sinais os mais diversos. A organização linear aristotélica do texto cede lugar a uma organização totalmente diferente, aberta, na qual cada sinal, cada imagem, torna-se polivalente, dependendo das múltiplas constelações simbólicas em que funciona. O texto de superfície escrito em inglês, com os nomes de seus personagens, suas referências geográficas, históricas, culturais e outras, funciona como um véu que esconde uma visão holística mitopoética sagrada (qualquer que seja sua natureza). Uma linguagem não-verbal, corporal, oral, dinâmica, cheia de formas em constante movimento e mudança se substitui ao texto de superfície. Esse método de análise exige uma confrontação constante com o texto de superfície que serve de suporte e com o contexto histórico, geográfico, cultural, social, político, econômico. Sendo nossa perspectiva antropológica, deixamos de lado uma leitura psicanalítica dos símbolos e sinais (3).

Para desarticular o texto inglês, os escritores fazem uso profuso de técnicas que provêm do que se chama "ciências ocultas": cabala, numerologia, alquimia, astrologia etc. Visto a facilidade com a qual os escritores usavam estas técnicas tão herméticas, pareceu-nos evidente que existe um contexto cultural que explica esse fenômeno. Organizamos três colóquios internacionais sobre as ciências ocultas na cultura norte-americana (4) e tivemos a satisfação de ver historiadores norte-americanos trazerem à luz a existência importante de um folclore rosacruciano transmitido pelos imigrantes alemães (5). Joseph Smith, autor do Livro de Mórmon (1830), descendia de três gerações de alquimistas (6). Um iluminado, afirmava ele traduzir para o inglês os escritos hieroglíficos dos índios, que tinham lhe sido revelados num sonho e que contariam a história das 10 tribos judias perdidas.

Hawthorne, Melville, Thoreau, Whitman e outros, cada um à sua maneira, em vez de pretenderem traduzir para o inglês sinais místicos, esconderam sob o texto inglês sinais os mais diversos por eles elaborados. Suas fontes não são somente de origem européia, mas também aborígenes e africanas. A superposição de sinais provenientes de culturas tão diversas torna a leitura muito árdua.

\section{A baleia preta de Melville}

O livro de Melville saiu em Londres em outubro de 1851, três semanas antes de sua publicação em Nova York. Tudo indica que Melville interferiu pessoalmente na composição tipográfica da edição norte-americana, o que lhe permitiu, entre outras coisas, como veremos, introduzir ou acentuar os elementos africanos.

O título do livro publicado em Londres é The Whale; sobreviveu uma prova tipográfica indicando que o mesmo título era previsto para a edição norte- 
americana. Melville mudou na última hora o título para Moby Dick; or The Whale. Visto a atenção que ele deu a este e o fato de que se trata da caça à baleia branca, estranha-se a ausência da palavra white no título definitivo. Da mesma maneira, nenhum capítulo se intitula "A Baleia Branca". O capítulo 41, "Moby Dick", é seguido pelo capítulo 42, "A Brancura da Baleia" (The Whiteness of the Whale), o que não é equivalente a baleia branca.

O título do livro estabelece uma equivalência entre "Moby Dick" e "The Whale". Ora, no capítulo 32, "Cetologia", o autor-narrador, gozando o fascínio da época pelas classificações dos seres (com todas as implicações de hierarquias raciais), dispõe as baleias, conforme o tamanho, em três livros subdivididos em capítulos. O primeiro livro, Folio, começa com o capítulo "The Sperm Whale", que quer dizer o cachalote - a palavra perdendo com a tradução toda a conotação masculina de dar vida. Muito jocosa e vaga a descrição desse cetáceo. O narrador diz que é também conhecido sob o nome de Trumpa Whale, nome inventado por Melville, mas que sugere um jogo translingüístico com o francês, no qual o verbo tromper significa "enganar". Da mesma maneira, o substantivo francês cachalot, usado parcimoniosamente no texto, significa cache a lot, isto é, cache ("esconde", em francês) a lot ("muito", em inglês). Moby Dick não é o que parece, esconde muitas significações. O segundo capítulo, "The Right Whale" ("A Baleia Franca", em português - right tem conotações outras em inglês), contrasta com a descrição do Sperm Whale. O mais antigo dos cetáceos é designado pelos títulos seguintes: The Whale, the Greenland Whale, the Black Whale, the Great Whale, the Right Whale. A letra maiúscula para o artigo definido refere The Whale ao título do livro. A indicação é clara, Moby Dick, ou seja, a baleia, a baleia preta, a grande baleia, a verdadeira baleia, a baleia certa. A classificação que o narrador propõe suprime a distinção entre branco/preto, masculino/feminino. A baleia (The Whale) preta pode se manifestar como branca, feminina, pode aparecer com um enorme pênis - evoca a divindade, o trickster africano e afro-americano Legba.

Essa baleia, The Whale, "que alguns chamam Moby Dick" (capítulo 36) é a baleia mais antiga; o Sperm Whale, com todas as suas conotações masculinas, não deixa de ser um mero usurpador. As implicações são imensas - desmorona-se toda a construção de identidade. Os capítulos 74 e 75 contrastam as cabeças amarradas ao navio: a do Sperm Whale e a da Right Whale. Dentro da cabeça do cachalote encontra-se o tão precioso spermaceti e o narrador descreve os olhos dessa baleia dispostos de tal maneira que tornam o Sperm Whale incapaz de perceber duas coisas ao mesmo tempo - crítica devastadora, a meu ver, da unilateralidade americana, infelizmente ainda tão atual. A cabeça da Right Whale parece um útero defeituoso, mas cheio de vida, e intimamente ligado à linguagem, à música. Essa baleia, a baleia original, é feminina, evoca uma deusa preta que dá vida e que precede o deus todo poderoso de Abraham (Gênesis: 17) (7). 


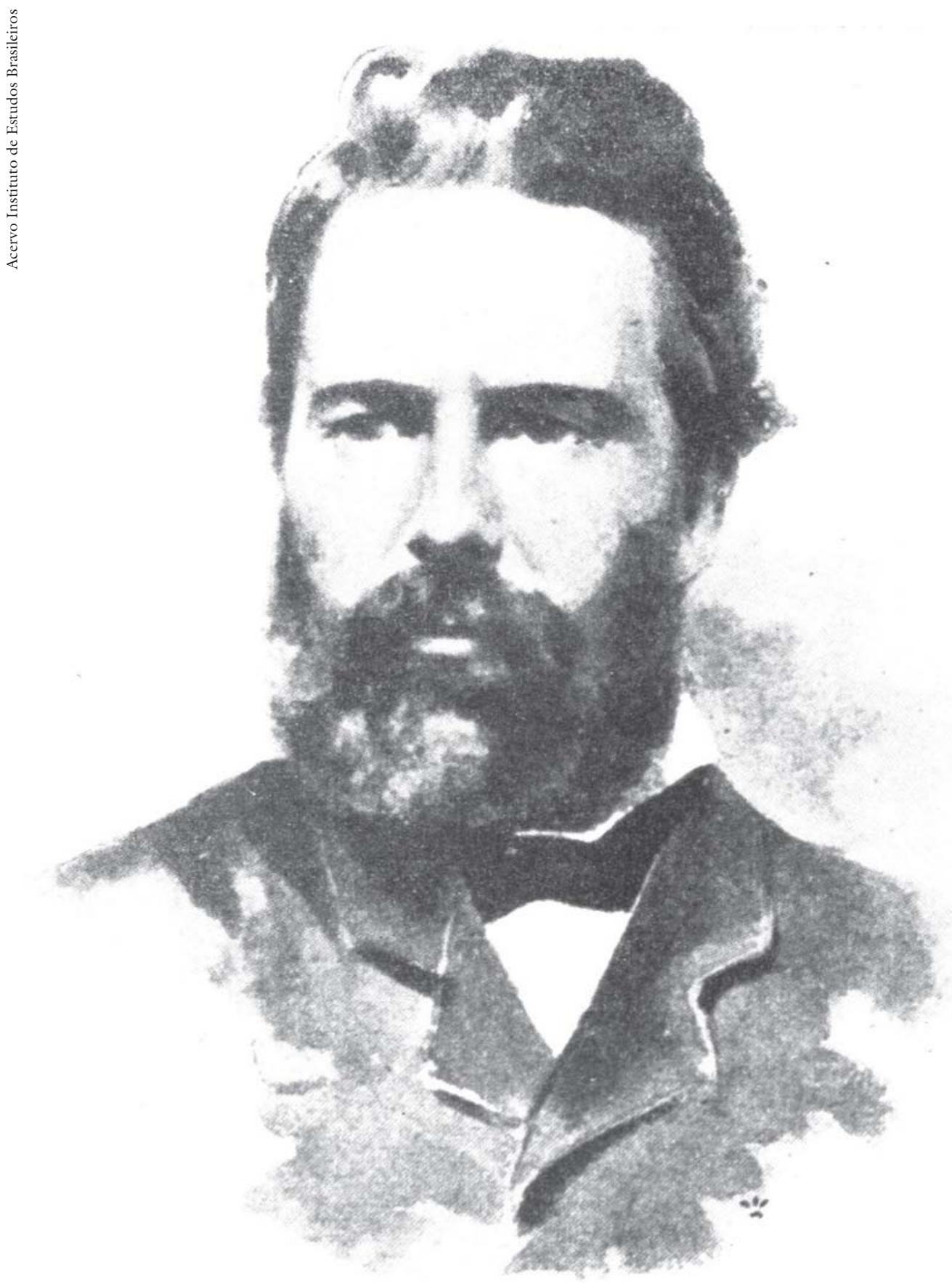

Desenho de Francis Day segundo fotografia de 1861, quando Herman Melville (1819-1891), autor de Moby Dick, tinha 42 anos de idade. 
rom a n e $\star$

Traduçăo de BERENICE XAVIER

Prefácio de

RACHEL DE QUEIROZ

280 ilustrações de ROCKWELL KENT e POTY

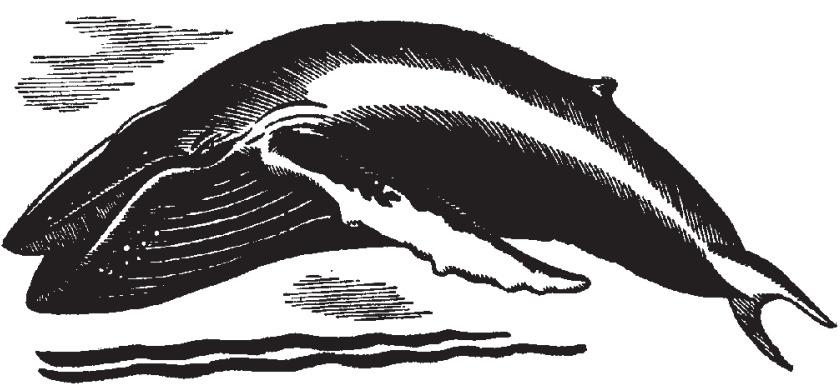

LIVRARIA JOS $O L Y M P I O$ EDITORA

Folha de rosto da $1^{a}$ edição em portugês de Moby Dick, de H. Melville, publicada no Brasil em 1957 pela então Livraria José Olympio Editôra. 


\section{As conotações hebraicas, africanas e muçulmanas do nome do narrador}

"Chame-me Ishmael"; assim começa a narração. Escolha estranha: não há dúvida de que Ishmael, sendo o grande rejeitado bíblico, poderia ter sido tratado como uma figura romântica, o que não é o caso. Acredito que a oposição a Isaac, o filho legítimo e herdeiro de Abraham, tenha sido, embora não mencionado no texto, um incentivo a essa escolha. $\mathrm{O}$ povo eleito de Deus, conceito tão importante na cultura norte-americana, descende de Abraham e Isaac, filho de Raquel (Gênesis: 17) (8). Ishmael é filho de Abram com a servente egípcia Hagar, que Sarai (sic!), por ser estéril, ofereceu a Abram (Gênesis: 16). Nos Estados Unidos do século XIX, Egito evocava a África negra (9). Melville concebe o seu narrador como não sendo, apesar das aparências, branco. Descobre ele a sua herança selvagem (wild man - profecia feita no capítulo 16 do Gênesis) graças a sua união com o canibal Queequeg. E preciso ter em mente que o filho de Abram, Ishmael, tornar-se-á um dos grandes profetas muçulmanos. Melville morava em Nova York, a 10 minutos de um cemitério recentemente descoberto onde foram enterrados 20 mil africanos muçulmanos. Não seria de estranhar que a sua existência tenha incitado Melville a desenvolver uma dimensão muçulmana inscrita no nome de seu narrador. As referências à religião muçulmana são numerosas. Meca e Roma, esta última tão detestada pelos puritanos, são postas num pé de equivalência positiva no capítulo 92 . Também não é por coincidência que o número do capítulo - 17 - que tem por título "O Ramadã" evoque por contraste o capítulo 17 do Gênesis, no qual Deus se manifesta como "o Todo-Poderoso", excluindo todas as outras divindades e outros povos que não sejam "perfeitos". O Ramadã celebrado pelo canibal representa um sincretismo religioso curioso: Queequeg fica de cócoras por 24 horas praticando uma simbiose de tempo lunar (noite) e solar (dia).

Um ídolo fálico africano está pousado sobre sua cabeça; o canibal é comparado a um New Zealand dog (leia-se, por inversão de letras, god) ou deus de uma "terra de nova crença" (Zealand: $z e a l=$ crença + land $=$ terra $)$ - uma pluralidade de crenças que contrasta com o Deus todo poderoso de Abraham.

A herança materna africana se manifesta no modo do autor-narrador elaborar o seu texto. O nome de sua mãe - Hagar - significa "vagar", "errar". Não há dúvida de que o leitor erra pelo livro e descobre uma pluralidade de significados, de verdades, através de certos erros (errar e erro são etimologicamente cognatos). Examinaremos a seguir os erros mais significativos que contrastam com a verdade puritana e que revelam de uma maneira indiscutível a presença cultural africana.

\section{Etymology, ou as origens do Logos/Verbo}

O livro abre com "Etimologia"; reproduzimos ela tal qual figura, com seus ditos erros tipográficos, na primeira edição norte-americana. 

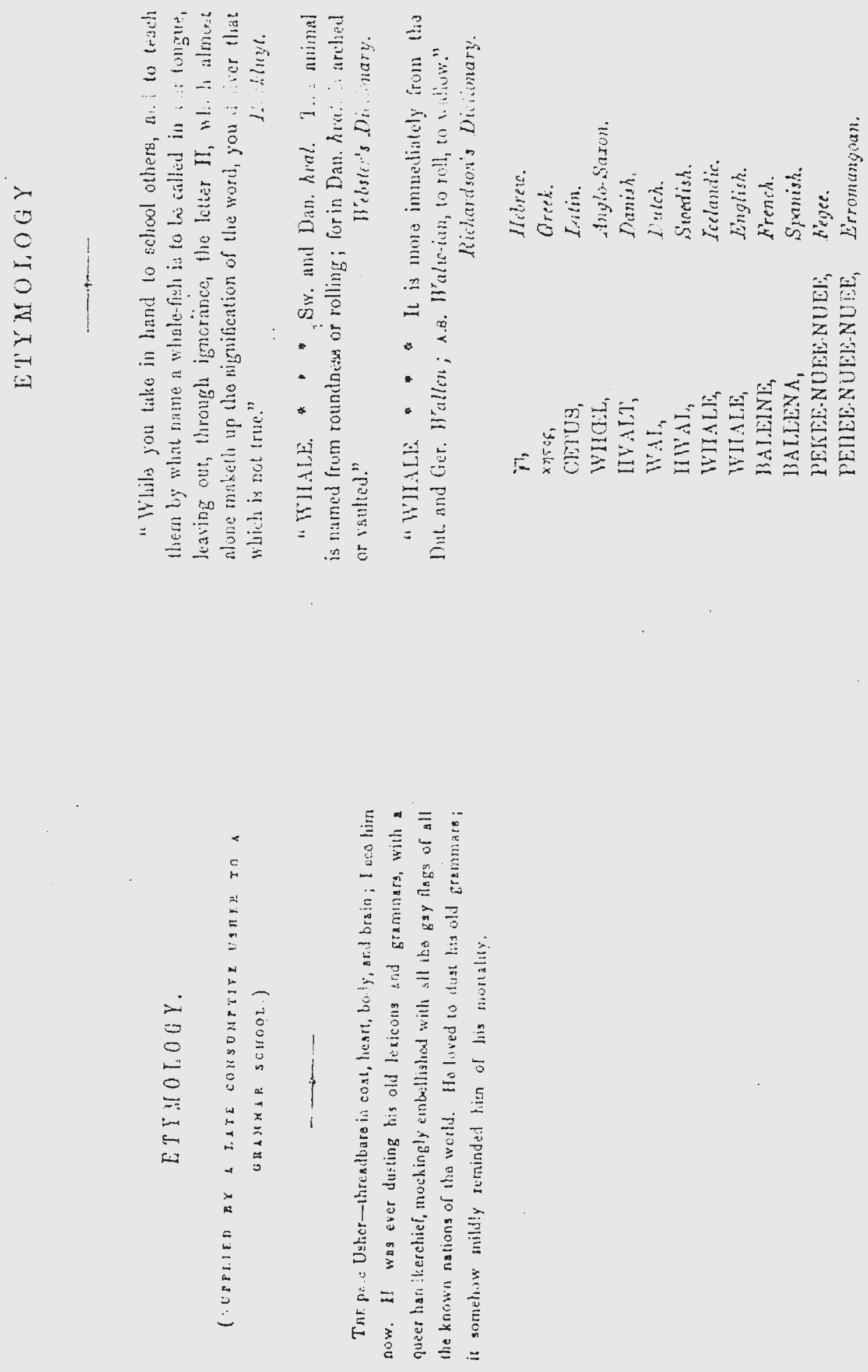
Por ser considerada errônea, infelizmente é raramente impressa sob essa forma. Cheia de erros significativos, examinaremos somente aqueles que se referem diretamente a nossa demonstração. Antes de proceder, note-se as alusões escondidas na história bíblica de Ishmael: a letra "h", na citação de Hackluyt, lembra a letra "h" introduzida no nome do pai de Ishmael (Gênesis: 17) e o número 13, dos 13 nomes de baleia em diferentes línguas, evocando a idade de Ishmael quando Deus fez a Aliança com seu pai. Este número liga intimamente a identidade de Ishmael com a da baleia (13 menções) e com a dos Estados Unidos, formados originalmente por 13 estados.

No primeiro capítulo, três linhas, aparentemente sem nexo, com tipografia jornalística exuberante anunciando jocosamente o destino de Ishmael, escondem essa relação: Estados Unidos/baleia/Ishmael - e, através da referência ao Afeganistão, a religião muçulmana.

Olhemos o texto, a disposição tipográfica do título "Etymology" na cabeça das duas páginas: o lado esquerdo, mais baixo que o lado direito, sugere a existência de um subtexto, um texto escondido. $\mathrm{O}$ mesmo acontece com a direção invertida da leitura - da direita para a esquerda, como na língua hebraica ou árabe, as duas línguas de Ishmael. O livro, aliás, inverte várias vezes as direções - a mais flagrante sendo quando o marinheiro experimentado que era Melville inverte a direção em que sopra o tufão no Pacífico. No capítulo 54, Ishmael está em Lima. O navio deve seguir para o Pacífico, ou seja, logicamente em direção "oeste". Ora, o texto indica "leste" - quer dizer, em direção à África, a volta à África?

O espaço branco, vazio, em frente aos vocábulos significando baleias em 13 línguas, lembra a reflexão de Ishmael no capítulo 42, "A Brancura da Baleia": se não conseguir explicar o que a baleia representa para ele, talvez todos os capítulos do livro sejam "nada". Essa ausência evoca também o "silêncio piramidal" do Sperm Whale (capítulo 79). Qualquer que seja a sua significação, não há dúvida de que esse espaço constitui um sinal.

A disposição das palavras sugere, entre outras coisas, uma perna (leg, em inglês). A perna perdida do capitão Ahab? Ou essa perna se refere ao preto rejeitado na construção dos Estados Unidos? O título do capítulo 93, The Castaway, evoca na cultura bíblica o destino de Ishmael, o grande rejeitado da Bíblia, ao descrever um pretinho cujo nome nem conhecemos - chama-se Pip, abreviação do apelido Pippin = a essência, a semente da maçã. Tendo pulado do barco na hora da caça, ele é abandonado de fato e perde a razão. Na véspera da caça final (capítulo 129), o pretinho suplica ao capitão que o leve consigo no barco. Diz ele: "O senhor não tem um corpo inteiro, use o meu no lugar de sua perna perdida" ( "but use me for your one lost leg, I ask no more, so I remain a part of ye”). Pip quer fazer parte de Ahab. Trágica essa recusa de aceitar, 10 anos antes da Guerra de Secessão, que o preto faça parte dos Estados Unidos/Whale/ Ishmael. 
A perna que vemos corresponde à componente africana dos Estados Unidos, Ishmael, da baleia, componente que Ahab recusa. A perna, em várias culturas africanas, como a dos mali e dos bambara, é símbolo da ligação social e sexual e da comunicação lingüística, enquanto o pé - tão grande aqui, formado pelos dois últimos vocábulos - simboliza o espírito. Na página central - 318 - da edição norte-americana de Moby Dick; or The Whale, que tem 635 páginas, no capítulo 61, cujo número constitui a inversão dos dígitos de 16, os três arpoeiros selvagens emitem três gritos:

\section{Woo-hoo! Wa-hee!}

Kee-hee! Kee-hee!

Ka-la! Koo-loo!

O grito central emitido pelo gigante africano é formado por sílabas componentes do pé. Estamos no centro do livro/"volume" de Moby Dick; or The Whale, ouvindo o famoso ring shout religioso africano e afro-americano. O espírito tão magnificamente descrito por Pierre Fatumbi Verger vem de baixo.

Da mesma maneira que Pip é uma abreviação de um nome que não conhecemos, secreto como era costume entre afro-americanos, leg é uma abreviação para Legba. Na cultura afro-americana, Legba (Exu) é considerado como o lingüista divino, o intérprete do livro de $F a$, texto sagrado na cultura ioruba, que abre caminhos desconhecidos, embrulha todos os sinais, muda constantemente de forma, de cor, de sexo e tem um interesse particular por línguas (10). No capítulo 104, no qual o autor-narrador discute a criação da escrita de Moby Dick, ele se projeta através de um jogo muito sofisticado sobre as letras maiúsculas - como o escritor John Leo (11), muçulmano da África do Norte, que viajou pela África, foi capturado por piratas, resgatado pelo papa João Leo, se converteu para o catolicismo, publicou seu livro em italiano, traduzido depois para o latim e a partir do latim para o inglês. Como Melville, teria ele sonhado a língua original de seu livro - certamente a língua inglesa não seria a língua original. Voltemos ao título da primeira página do livro, "Etimologia": qual é, de fato, a origem do Logos, do Verbo, do Mundo - uma língua africana?

\section{$\mathrm{O}$ ritmo do blues}

Um erro escapou a todos os estudiosos de Melville: na página 37 da edição original norte-americana, em vez de anunciar o título do capítulo novo que segue na mesma página "A Igreja" ("The Chapel”), aparece o vocábulo Blue. Tudo indica que não se trata de um erro de composição mas de uma introdução ciente dos ritmos afro-americanos. Os dicionários afirmam que o blues só aparece no sentido musical nos meados dos anos 1860. Moby Dick sai em 1851. Tudo indica que esse é o primeiro exemplo de uso escrito desta palavra - que, aliás, já denota o negro.

O erro ocorre no capítulo 6, intitulado "A Rua". "Rua" evoca o mundo profano, enquanto "igreja”, o sagrado. Como no blues não há distinção entre profano/sagrado, o texto da página na qual ocorre o erro se refere à arte de 
criação e àquilo que foi descartado na criação do mundo. Arte de criação evoca um dos 80 extratos (a numeração por ordem é velada, trata-se de um extrato do Leviatã, de Hobbes, que fala da "arte de criação do grande Leviatã ou Estado". O número do extrato -21 - corresponde ao valor triangular de $6(6 \times 7 \Rightarrow 2=21)$, número do capítulo "A Rua”. O número da página errônea - 37 - poderia aludir, se Melville tivesse conhecimento disso, à terceira e sétima nota do blues, que destoam (12). Mais um detalhe confirma que esse erro é intencional: se multiplicarmos o número da página errônea - 37 - pelo número 21 do extrato que fala da arte de criação do Leviatã (quer dizer, de Moby Dick, descrito muitas vezes como Leviatã) obteremos o número 777, que corresponde à parte dos lucros da viagem prometida a Ishmael (capítulo 16) - parte absurda, porque um marinheiro inexperiente recebia a trecentésima parte dos lucros (13). Há 50 menções a blue, sob várias formas, no livro. Na numeração romana, que aliás Melville usa para os capítulos, 50 = L, figura que as diferentes palavras para baleia dessinam na "Etimologia". Leg/Legba comunicaria não somente em diferentes línguas mas também em ritmos e, quem sabe, a perna da baleia evocaria pela sua forma um instrumento musical primitivo. $\mathrm{E}$ as $21(21=$ arte de criação) notas (foot/notes: foot = pé, em inglês) que Melville introduziu em baixo das páginas do livro exprimiriam ritmos musicais criados pelos pés dos pretos?

O capítulo 106 (16) intitulado "Ahab's Leg” trata não tanto da perna do capitão como dos sinais divinos de alegria e de dor, sinais inscritos em inglês no nome de Abraham, nome do pai do narrador Abr/ah/am ou/e Abra/ha/m. Estas sílabas, "ah" de dor e "ha" de alegria, usadas com muito cuidado no texto, lembram o ritmo triste-alegre "gloomy-jolly" do tamborim, instrumento africano, de Pip (capítulo 93). O ex-escravo Frederick Douglass, em seu livro My bondage and my freedom (1855) descreve as "wild wailing (homófono de whaling) notes" das músicas africanas (14).

Melville não é uma exceção (15), embora tenha sido provavelmente o escritor que naquela época mais introduziu elementos culturais africanos em sua obra. É muito difícil para um leitor branco que não tenha vivência com essa cultura do outro (sem falar das culturas aborígenes que deixei de lado por incompetência) perceber tais dimensões do texto. Seria necessário que os universitários norte-americanos brancos e afro-americanos quisessem trabalhar juntos - a reticência é mútua. Ao mostrar o capítulo 40, que sempre me pareceu muito enigmático e que descreve uma reunião de toda a equipagem, ao professor Sterling Stuckey, autor do famoso livro Slave culture (16), ele logo percebeu as danças e ritmos africanos (17).

Essa cooperação interdisciplinar é tanto mais importante quanto estamos confrontados com um fenômeno cultural que, pelas circunstâncias únicas da colonização do país, criou, apesar das aparências enganadoras, uma literatura que qualificarei de híbrida (18).

Paris, fevereiro 2002. 
(6)

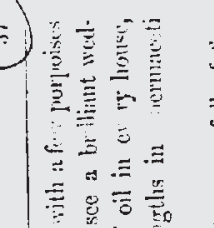

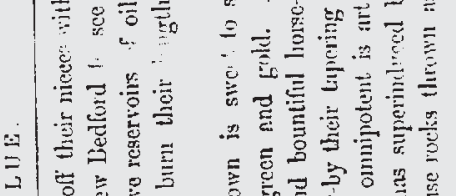

至

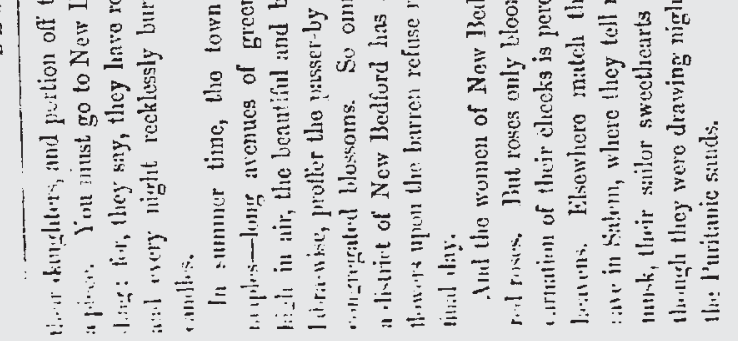

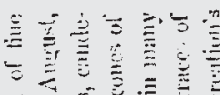

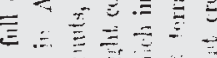

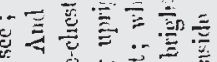

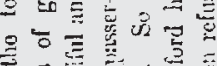

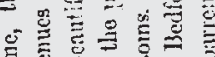

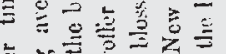

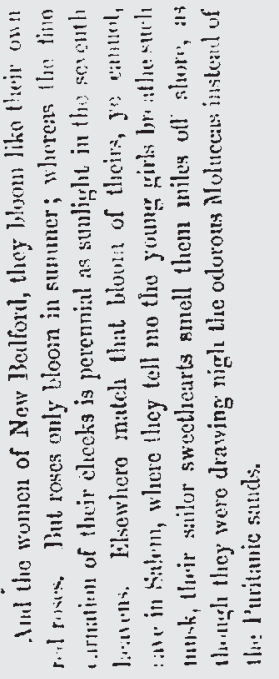

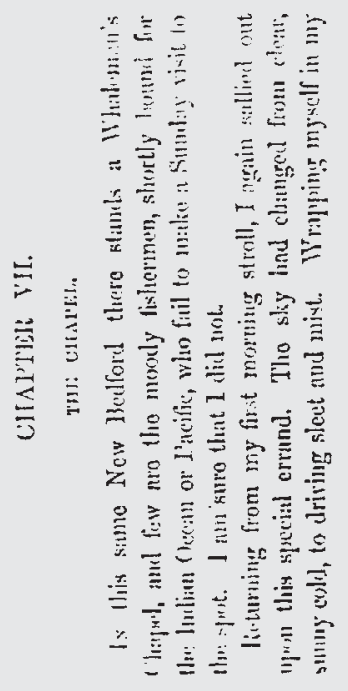

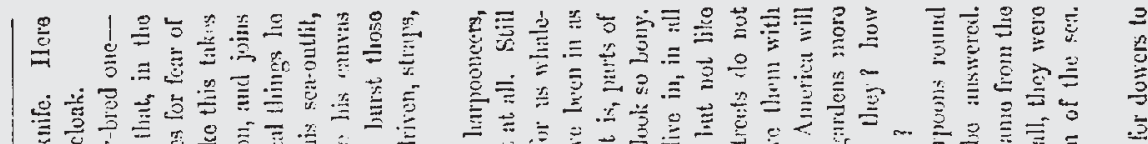

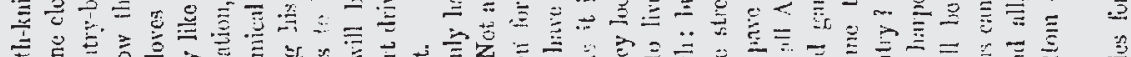

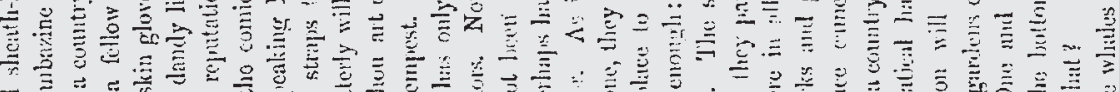

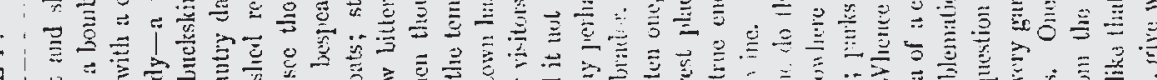

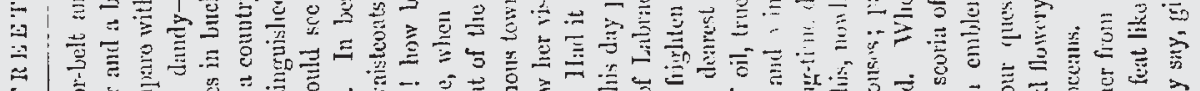

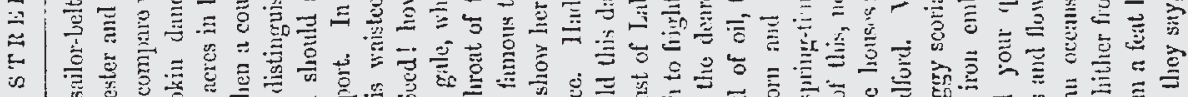
及

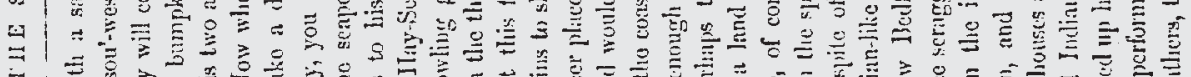

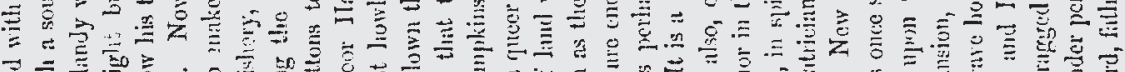

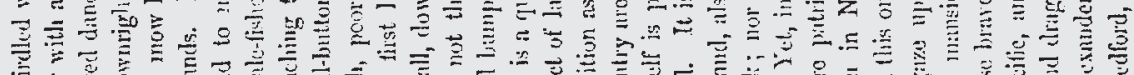

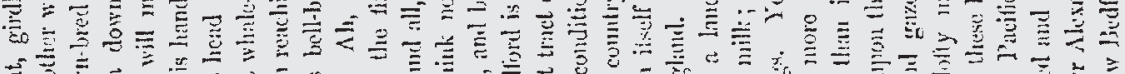

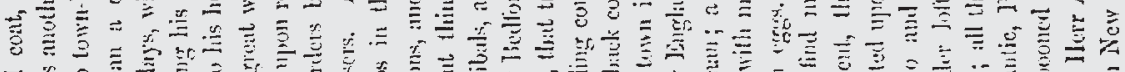

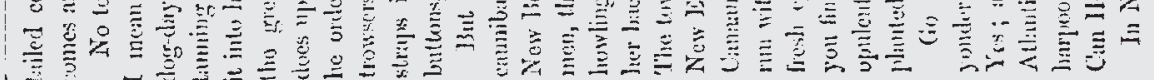




\section{Notas}

1 Shelley Fisher Fishkin, em "Interrogating 'whiteness', Complicating 'blackness': Remapping American Culture", American Quarterly, 3, 1995, mostra até que ponto não havia pesquisas sobre o problema da influência africana até os anos 1970. As pouquíssimas exceções vinham de historiadores ou escritores, raramente de críticos literários. Ao publicar meu artigo "The Gnosis of Hawthorne and Melville: An Interpretation of The scarlet letter and Moby Dick", que argumentava que a baleia branca era de fato preta, a American Quarterly, no 2 (1980), numa nota tirou toda a responsabilidade da redação pelo conteúdo do artigo.

2 Cf. Dana D. Nelson, National manhood: capitalistic citizenship and the imagined fraternity of white men (Durham: Duke University Press, 1998).

3 Cf. Gilbert Durand, L'imagination symbolique, $4^{\mathrm{a}} \mathrm{ed}$. (Paris: Presses Universitaires de France, 1989) e também Lesstructures anthropologiques de l'imaginaire, $9^{\mathrm{a}} \mathrm{ed}$. (Paris: Bordas, 1982).

4 Paris: Maison des Sciences de l'Homme, 1982, 1984, 1987.

5 Sobre a participação do movimento rosacruciano na Reforma e sua linguagem muito esotérica, veja Frances A. Yates, The Rosicrucian Enlightment (Londres: Routledge and Kegan Paul Ltd., 1972). Veja também Sachs, "As Escrituras Sagradas e a Escritura da Nova Cosmogonia" em Brasile EUA: religião e identidade nacional, apresentação de Viola Sachs (Rio de Janeiro: Edições Graal Ltda., 1988) e também Sachs, "L'Argent, la Sainte Alliance et l'Identité Américaine" em La rencontre des imaginaires entre Europe et Amériques (Paris: L'Harmmattan, 1993).

6 Cf. John L. Brooke, "Of Whole Nations Being Born in One Day: Marriage, Money and Magic in the Mormon Cosmos, 1830-1846" em Information sur les Sciences Sociales, $\mathrm{n}^{\circ} \mathrm{l}$ (março 1991).

7 Assim, a letra hebraica correspondente ao "h" no alfabeto foi introduzida por Deus no nome de Abram em sinal da aliança. Visto a importância de letras como sinais e símbolos nos textos, guardarei a escrita inglesa; igualmente usarei quando necessário a palavra inglesa.

8 Isaac conota o povo eleito; em The Hamlet, o Isaac de Faulkner é um débil mental. Embora tenha uma relação amorosa com uma vaca, é o único membro do clã dos Snopes, dominados pela ganância, que é humano. Através do nome desse personagem, Faulkner critica de uma maneira devastadora a identidade americana.

9 Cf. Lydia Maria Child, An appeal in favor of that class of Americans called Africans (1833), Carolyn L. Karcher (ed.), (Amherst: University of Massachusetts Press, 1966). Veja também Janet Gabler-Hover, Dreaming black, writing white, the Hagar myth in American cultural history (Lexington: The University Press of Kentucky, 2000).

10 Cf. Henry Louis Gates, Jr., The signifying monkey: a theory of African American literary criticism (Nova York: Oxford University Press, 1989).

11 Veja Sachs, La contre-Bible de Melville: Moby-Dick déchiffré (Paris: Mouton, 1975), pp. 31-32.

$12 \mathrm{O}$ narrador do romance de Ralph Ellison, Invisible man, ao parar no fim do livro num 
celeiro em Nova York, acende 1369 luzes ( 37 x 37) com a eletricidade que rouba da companhia elétrica. Visto a importância do blues no romance, é interessante que ele, como Melville, tenha usado este número.

13 Veja em Sachs, The game of creation: the unlettered primeval language of Moby Dick (Paris: Edition de la Maison des Sciences de l'Homme), pp. 124-29, implicações outras, revolucionárias, do número 777.

14 Sobre a importância da música, línguas e sons africanos, veja também Frederick Douglass, Narrative of life of Frederick Douglass, an American slave (1845) (Nova York: Library of America, 1994).

15 Nesse contexto, veja o livro importante de Shelley Fisher Fishkin, Was Huck black? Mark Twain and African American voices (Nova York: Oxford University Press, 1993). Veja também Sachs, "An Outsider's Conjectures on Mark Twain and Black Culture”, Rivista de Stidi Vittoriani, v, n ${ }^{\circ} 9$ e n ${ }^{\circ} 65$ de Letterature d'America (Roma) e "The African Dimension of American Literature", baseado nos trabalhos apresentados no colóquio organizado pelo Laboratoire de Recherche sur l'Imaginaire Américain na Maison des Sciences de l'Homme em 1996.

16 Sterling Stuckey, Slave culture: nationalist theory of the foundations of black America (Nova York: Oxford University Press, 1981).

17 Veja "The Tambourine in Glory: African Culture and Melville's Art" em The Cambridge companion to Herman Melville (Cambridge: Cambridge University Press, 1998).

18 As reflexões apresentadas nesse artigo emanam de trabalhos de trinta anos de pesquisas feitas no Laboratoire de Recherche sur l'Imaginaire Américain da Universitdade de Paris VIII. Uma bibliografia detalhada, mas que só vai até 1991, acha-se em "The Occult and the Occulted in American Literature: A Backward Glance at Two Decades of Research", Information sur les Sciences Sociales, no 1 (1991).

Viola Sachs trabalha no Laboratoire de Recherche sur l'Imaginaire Américain da Université de Paris VIII, França. 